\title{
The Conversion of the Lom belief through the Transformation of Islamic Religious Education in the Mapur Tribal of Bangka District. Bangka Belitung Islands Province, Indonesia
}

\author{
Janawi \\ \{janawi.iainbabel@gmail.com\} \\ State Islamic Institute of Syaikh Abdurrahman Siddik Bangka Belitung, Jl Raya Mentok Km. 13 Petaling \\ Bangka, Indonesia
}

\begin{abstract}
The transformation of Islamic religious education among adherents of Lom ancestors' beliefs is one of the essential factors of Lom believes Conversion. Islamic religious education has been performed for a long time informal school process and in non formal process. The study was conducted in-depth regarding the Conversion of the Lom belief through the transformation of Islamic religious education scattered in several villages and sub-districts in Bangka Belitung province. This study was an ethnography study with a religious-anthropological approach and used the functionalism theory of Parsons. Data collection used observation, in-depth interviews, and documentation. The results showed that generally, the Conversion of beliefs was occurred through the transformation of Islamic education in schools and community activity, besides the marriage factor. Even though they have become a Muslim, but they still endured and performed the cultural system of ancestor belief.
\end{abstract}

Key words: transformation of Islamic religious education, orang Lom, Conversion of beliefs.

\section{Introduction}

The Lom [1] is one of the ancestral believers (indigenous religion) scattered in the geographical region of the northern part of Bangka (Bangka district), Bangka Belitung province. As believers included other tribes such as (Badui-West Java, Kaharingan Kalimantan, Kubu - Jambi, and others in Indonesia), many of the genealogical community of believers were experiencing religious Conversion, including the Lom. As ancestral believers, they still considered it essential to learn formal Islamic education in elementary school. Their children were also allowed to learn to recite Qur'an in the Qur'an Education Park (TPA). So it did not surprise the children of People Lom Elementary school age (6 - 12 years) could read Qur'an. However, after their children continued to junior high school (SMP), parents began to prohibit their children from learning about Islam, such as faith. Nevertheless, the Lom community, interacting directly with the culture and values of religious teachings in the community, such as Christian, Islam, and Khonghucu. Interaction and communication with religious adherents, especially Islam as a majority, not only an artistic touch but also a touch of the values of religious teachings that differed from the beliefs of the ancestors.

Besides the marriage factor, the transformation of Islamic religious education was considered to be one of the dominant variables for the Conversion of the people of the Lom. However, there was a clear difference between both factors. Generally, marriage conversion did not form a strong character as the official state religion. The citizenship identity and 
identity of beliefs were changed, but they did not practice religious teachings. Religion seemed to be just a formal identity. While Conversion through Islamic education has resulted in personal changes as a religion, which was state-recognized, although they also could not fully release their ancestors' practices, in the trust structure of the Lom, when embracing religion and carrying out religious teachings totally, the person was deemed to have been detached from family relationships. The disobedient descendants of the abature and the ancestral ban, they referred to as the damned people and the cursed offspring.

\section{Method and Approach of Study}

This study included qualitative research focused on field research using ethnographic studies. Anthropology of religion was used as an approach in this study. Data collection is done by several techniques, namely participatory observation, in-depth interviews, and documentation. The observation of participation was used to observe the symbols of the Lom belief structures, their interactions with the formal religions, the formal religious symbols adapted into their beliefs, the ordinance of performing their rituals, and the implementation of Islamic religious education both formal in school and non-formal in the community. In-depth interviews were conducted to obtain data on the process of implementing Islamic religious education in schools, the implementation of Islamic religious education at TPA, the intensity of the use of symbols of Islamic culture and teachings, the touch and interaction of the Lom With the values of Islamic religious teachings, causes of Conversion, behavioral patterns after Conversion, and the reason for choosing Islam as a religion adopted. Key informants were taken from the indigenous peoples, indigenous leaders, indigenous peoples, Islamic religious teachers in elementary school, teachers of the Koran in TPA, Islamic religious leaders, and communities that have embraced the official religion. The documentation was conducted to trace the identity of the trust and identity of the Lom in Gunung Pelawan head office and Gunung Muda village.

\section{Theoretical Framework}

The study of the Lom was not preliminary research. The terminology Lom (Lom people) as one of the Mapur community in Bangka Island has been mentioned in colonial reports. Thomas Horsfield (1848) dan Heidhues has mentioned in his report that Lom people were hill people and land people[2]. Sujitno said that Lom people believe as the first tribe in Bangka island[3]. Soekanto said that Lom people of malays lived in Bangka island [4]. Zelle in Les Maporais, Adatrecht: Banka[5], has been observing the people of Lom 13 - March 1898. A comprehensive study was the anthropological study conducted by Smedal [1] as Order and Difference: An Ethnographic Study of Orang Lom of Bangka, West Indonesia. The Smeal illustrated that the Lom has distinct characteristics with the Malay and ethnic Chinese people of Bangka. The Lom were tied to a custom called "Custom Mapur" and a belief in myth, magical, deity, Anima, and synonymous with the totem. The belief was identical with the belief that primitive society spread in Nusantara. They were banned from eating certain types of animals, such as the kancil, deer, stag, pangolin, civet, monkey, squirrel, turtle, and kalong, but in practice, they hunted the animals for sale. Rules imposed by ancestral customs chaired by the Chairman of Adat. If there is deviation, the customary law becomes a reference through the customs siding, because the customer has a high position and bind the life of society. Smeal, therefore, concluded that the Lom had different characteristics of the Malay 
and ethnic Chinese people of Bangka. The Lom is tied to a custom called "Custom Mapur" and a belief in myth, magical, deity, Anima, and synonymous with the totem. The belief is identical to the belief that primitive society spreads in Nusantara.

The study differed from Smedal and Zelle. This study focused on the Conversion of beliefs that occur in the Lom after interacting with Islamic studies in schools and communities. The two equations were using ethnographic studies. This study used the functionalism theory of Talcott Parsons [6]. The theory of structural functionalism-in this paper- was used to describe Lom's problem in maintain its traditions and beliefs and to analyze the influence of the touch of religious teachings of the Lom, which was packed with the focus transformation of Islamic studies on the Conversion of the Lom people. Functions were interpreted as all activities directed to meet the needs and needs of a system. Using that definition, Parsons argued that four absolute requirements must exist in order for a society to function. The four requirements were called AGIL. AGIL stands for Adaptation (A), Goal Attainment (G), Integration (I), and Latency [pattern maintenance] (L). The AGIL Parsons system was used as a concept of analysis of the touch and relationship of the Lom with Muslims, including Islamic religious and cultural teachings. AGIL was not used as a description material about the social life of the Lom people.

The Result changing process of Islamic religious education of the ancestral believers gave a significant role in some aspects of the Lom people's lives. For the continuity of his life, the Lom as a community order should perform the functions, namely: First, adaptation, including interactions between society and the outside nature although the belief of the Lom people persist, They also conformed to their environment and even the Conversion of belief; Second, goal attainment, including the adjustment of resources to achieve the goal. A system can be able to determine its purpose and strive to achieve the objectives it has formulated; Third, integration, centered on alignment in the entire social system. The community should regulate the relationship between its components so that they could function optimally; and fourth, latency (latency), the maintenance of underlying patterns included interactions with communities and the inner metaphysical environment, and centered on the stabilization of crucial values that individuals embraced into patterns of social values. Latency tended to maintain and maintain existing patterns. The Lom people tended ambivalent between retained their trust try to improve and renew personal motivation from dominant cultural patterns.

These four functional requirements related to the four action systems of the Lom people. The system of biological organisms in action systems was associated with adaptation functions, namely adapting to the environment and changing the environment according to the needs. The personality system served to accomplish the objectives by moving all resources to achieve the objectives that have been formulated. The social system related to the integration function by controlling the components of the community's forming. Finally, the cultural system related to the maintenance functions of existing patterns or structures by preparing the norms and values that motivate them to do something[7]. In that condition, the Lom adapted Islamic religious education at the school process and outside the school to get an education. They adopted the rules of marriage according to formal religion to gain recognition from the government. Even Symbol-Islamic religious symbols were specially adapting into a new system of belief. This pattern was practiced continuously and has an impact on trust conversion. 


\subsection{Structure of touch and transformation}

Tylor in Daniel L. Pals explained that the belief of a primitive society would experience the evolution of polytheism into monotheism. Religion has developed from the primitive belief of the spirits in the trees and rocks to the highest levels, namely monotheism and ethics [8]. Similarly, culture, that all cultures in the world must evolve through the increasingly complex levels of progress, or the term cultural evolution. In this process, there is always a learning process, called an acculturation process[9]. Although the pace of cultural evolution is not the same, cultural evolution can touch essential elements such as religious systems, kinship systems, livelihood systems, languages, and others. Dialectics are indicating that the economic system is faster than the legal system; The legal system is more rapidly evolving than a kinship and family system; While the kinship system is faster evolved than the religious system (religion and belief). This differential evolution [10] also occurs in the Lom. The evolution of the belief system is more sluggish, it does not mean there is no shifting to the structure and value system that the Lom people possess.

\section{Research findings}

Conversion of the Lom people's beliefs does not happen incidentally. Conversion occurred based on the transformation of Islamic religious education, through the education process in schools and outside schools. This process has been ongoing for a long time and ongoing. As with the Parsons theory that Conversion occurred through several stages, namely adaptation and integration. Adaptation is a self-adjusting process; adjustments to the environment; work and lessons [11]. The process of adaptation that occurred among the Lom through the adjustment of values, symbols, belief systems, and cultural attitudes of the teachings of Islam has been studied formally or based on the relationship symbolic culture. Adaptation connected the system of two cultures or more between the system of religious teaching values and the dominant cultural system with the cultural environment of the People's Lom minority. The adaptation process has been occurring for a long time in the relationship of the symbolic interactionism process. The symbolic interactionism emphasized the role of two artistic touches between Islam and customs.

Integration as the next stage is a process of deforming to a whole unity. In evolutionary theory, integration through several stages. First, the stage of entry of new values (Islamic religious teachings) that interact with the initial value of local culture (people of the belief of ancestors who have identified animism and paganism. Second, antithesis-synthesis stage. This stage can be referring to as the Receive-Reject stage. For the Lom, new cultures are entered as bidders. New values are accepted and rejected or called the process of integration and disintegrating. Third, acceptance and rejection. The value is acceptable or rejected, depending on how intense the agent stimulates its existence. The acceptance of Islamic religious values is not separated from the adaptation stage and the acculturation of two cultures.

In the Lom culture system, integration also adhered to evolution, which can lead to cultural differential construction. For that, the evolutionary differential in the system and belief structures of the Lom indicates a shift in cultural systems, including belief systems. Culture of the Lom that previously became a reference to the privatization of local religion began to shift after contacting with the value and system of Islam religion. In this context, the culture of the Lom experienced a crisis, although their belief system could still be controlled. Control was done by incorporating a framework of integration, adaptation, and acculturation of significant cultures, especially Islam. In other words, the slow sea of the old belief system undergoes 
destruction. In such circumstances, the process of education as a distribution agent of a cultural system, religious system, the values of Islamic religion affects the attitude of Conversion of belief. The Lom should to diffuse and eventually try to accept new values, Islamic religious teachings. Because geographically, they have been living in a significant community that applied the values of religious teachings. Moreover, they believed that Islam was a religion that is sacred and needs to be learned. Islam was not only religion but also knowledge, so they do not prohibit the children from studying it in school or outside school.

The Lom not only follows an integration process but also tends the disintegration process in the global system. The intensity of the spread of Islamic religious values constructed the Lom culture system as a process of integration, adaptation, resistance, even a form of disintegrating. The process of the localization culture occurred in identifying the global cultural conquest efforts on minor culture. The values of the global culture or high culture undermined local cultures, including religious systems owned. In such a position, to preserve the local culture, the Lom unwittingly adopted the large cultural values around it. The integration of Islam as high cultural acculturation was adopted and even became an ideological synthesis or new value structure. The integration also formed the norm, morals, values, and rules of a prenup in the community from the symbolic abstraction of high culture.

The process of acculturation and integration as the AGIl Parson theory presented; First, the inner opposition of the Lom between firmly grasping the principle and fundamental pillars of ancestral inheritance by adopting a new value system as the dominant cultural system; Second, filter new values and norms and include them as part of the old value system; Third, incorporate a new value system as an essential part of ancestral inheritance; Fourth, carrying out old values and new values as an integral part of the ancestral belief system. That is why they believe in the Lord (Almighty, God Taala, and Ruler of the universe), Prophets, angels, Heavens, and others who are sacred and profane.

The Lom trust was considered to be a significant change after continuing contact with the Muslims. The concept of God, angels, prophets, and verses were not found in the system and structure of animism or on the belief of primitive peoples. The basis of animism was the belief in spirits and gods with the nature and form of their faith rituals. God, angels, prophets, and verses were essential pillars in the system and structure of the Lom. These concepts contradicted animism. The concept was the integration, adaptation, and acculturation process of Islam.

Conceptually, the terms used by the Lom were an adaptation of the basic principles of the State's formal religion, the Islamic religion. Even these terms are the fusion and acculturation of the Lom with Islamic teachings. Because the Lom and Muslims have been living in the same area for a long time, this fact could be noted from the basic principles of Islamic teachings. The interaction of the Lom people with Muslims touches all aspects, not only the basic teachings of religion but the socio-cultural relationship. On the one hand, the encounters of two cultures and beliefs produced various changes. The dominant culture -Islam- affected to the belief system adopted by the small culture, Lom people. It has happened, which is similar to the theory of cultural imperialism. The dominant culture and technology will affect a significant stimulation of small cultural changes. On the other hand, the Muslim community has spread and interacted with the Lom since early Islamization, especially the people of the Lom Mapur or Karel Lintang.

According to Assa Brigs \& Peter Burke [11], educational aspects were one of the trinity of information, in addition to the information itself and entertainment. The Trinity theory had existed before it was fashionable, known as the term information society and information technology. This trinity cannot always be identified with the same language. Information was 
generally explained in the 17th and 18th centuries with intelligence; Education was understood as a lesson; and entertainment as a recreation, time killer, or pleasure. These three components were considered to have a significant influence on the social change of people in all aspects of life. Then, public access to the education process was increasingly needed in every segment of life, both modern society, and still pure society.

Transforming the teachings of Islam in the Lom, primarily through the process of education, is a cultural process. Everything that was created, enforced, and perceived as a result of learning[12]. The culture was a transformation of value that can form attitudes. One of the values transformed among the Lom was the values of islamic teachings. The transformation values, including symbols and signs of Islam, have held since the Islamic role establishment of the Lom people. The process of transformation among the Lomwas not separated from the three main components, namely society, social interactions (processes and patterns), and education. The Islamic and indigenous peoples were a reality in which there was a process of social interaction, and there was a pattern of social interaction. The relationship between society and education was mutually affecting or reciprocal relationships.

\subsection{Educating Process in the Formal School}

As previously revealed, education is the process of transforming cultures which have a function of transfer or inheritance of value and culture. The educational institution served as the devolution and value transformation process. The devolution of value can be: First, the inheritance of the sublime values of socio-cultural; Second, the devolution of religious values of religion; third, knowledge transformation; and fourth, character formation. Educational institutions have a significant meaning for the life of mankind when it can function; First, manifest function (visible function); and secondly, the latent function (the covert function) [13]. The manifest function is the real consequence that contributes to the adjustment of the system as desired and realized by the participant. While the latent function is the real consequence of a cultural problem that is not desirable or realized by society.

The educational Institutions in the Lom community were constructed as a system, pattern, and organization. As a system, education institutions) were held sistimatically. One component with the other is inseparable. As a pattern, educational institutions offered a modern education system and did not eliminate the principle of local wisdom. As an organization, educational institutions are the learning process.

The institution of the Lom community has been held since the 1970s. On the shores of Pejem, the elementary school level education institute was built by the government in 1971, known as social post. The school conducts a schooling system and subject matter as it is generally applicable in Indonesia. Islamic religious studies are presented as mandatory subjects. The children of the Lom formally participated in Islamic studies in school. Until the beginning of 2015, children and parents of the indigenous community never complained about the giving of islamic religious education in elementary and Junior high School. 14 studens of the 34 elementary school students were the hamlet of Pejem. Besides that are seven junior high schoolers, the Lom. Besides, the people Khonghucu followed subjects, forced children of Islam.

Different from the hamlet of Air Abik, elementary school was built in 1978. However, the Islamic religious lessons were not allowed by the indigenous peoples to be delivered in elementary school until the end of 2006. The value of PAI lessons on elementary school for the children of indigenous peoples was cleared. Although the principal has the initiative to fill 
the value of religious lessons in the diploma, the parents (indigenous people) still did not approve it.

They argued why the value is to be filled, while our children do not receive the lesson at school. According to them, the prohibition is caused by the prohibition of ancestral customs. They assumed PAI is devoted to Muslims, not for indigenous people. Judging from its essential teachings, Islam is contrary to ancestral belief. Indigenous people consider Islam to be a sacred religion. Something sacred should not be in the common area. Islam can not be separated by the learning process of religion. Islam is understood as a formal and permanent structured organization.

Islamic studies in schools are likened to mosques (Mushalla or Langgar), as a place of worship. The submission of PAI material at school and islamic teaching in Mushalla was prohibited. The prohibition of formal enforced, because the elementary school and Mushalla was formal organization and place of worship was a formalism of the substantive symbols of Islam. Mushalla In addition to islamic physical symbols. Islamic religious lessons contradicted the principle of ancestral indigenous beliefs. However, the people of Abik Lom did not prohibit Muslims from implementing Islamic teachings at home as personally or collectively. Abik Lom prohibited muslim performed prayer in Mushalla. They permitted praying at home personally or collectively. Mushalla prohibited using since mushalla was built in 1970an until now. Thus, the Islamic religious lessons as a curriculum in the school did not affect the Air Abik Lom until the year 2006. The influence was only seen after the islamic religious lessons (PAI) was included as a subject in the Air Abik Elementary School after 2006.

PAI as a subject in school prohibited because PAI lessons contradicted to Lom belief systems. The prohibition is a customary protection step. In this context, the Lom constructed islamic religious lessons have manifest functions. Although the people who have been Muslims, whether the people of the Lom or the relocation of shelter, can perform prayers and others. But the azan with loud noises though done at home was contrary to customary belief.

Adzan was considered to be not as apparent as the customary spirit. With the chanting of Azan, Jinn and Ghosts will wrath. Some of the jinn (ghosts or the like) that they have will show attitudes; First, angry and ran; and secondly, angry but will make a fight. In other words, the attitude shown by the Genie and the Ghosts is frontal and also waiting for a turn to make calculations. These delicate creatures will run into the woods. However, the genie and the Ghost will make a fight. The resistance is done by the owner of delicate creatures in various ways.

In Air Abik, the development of Islamic culture in the last ten years is more dynamic, although not as intensively in Pejem. The performing of PAI subjects at school began to change the view of the Lom. In effect, Elementary and junior high school-age children have become acquainted with Islam. In dressing, for example, some teenagers and parents who have embraced Islam began to use the hijab. Islamic symbols, such as the hijab, indicated formal differentiation of beliefs. Adaptation and acculturalization of religious teachings began to give the dynamics of the practice of socio-cultural values. Some changes were seen in the use of Islamic verbalism, views on ancestral customs, mythology and cosmology systems, attitudes, and elements of social culture.

\subsection{Education Outside School}

Education outside the school--as the formulation of education under the legal law number 20 years 2003 about the national education system--was an educational category that has significant implications for students. Outside school education was intended in the form of the Islamic religious education process held outside schools such as at home and in the 
educational park of the Qur'an (TPA) or Council of Ta'lim or children's studies (non-formal education). Judging from the function of inheritance and learning, religious education outside of school, in addition to educational rides of the nation's high values, also has essential functions in the transformation of religious teachings, strengthening internalization, and habituation of teaching practices Religion. The informal organization's presence is essential in the content and values of Islamic teachings.

\subsubsection{Religious studies at home}

In particular, the process of learning Islam at home was given by parents (father, mother, brother, and Ustadz). The learning process has been performed for a long time, both in Pejem and Air Abik. Parents who have embraced Islam both from the Lom and outside people from other regions and settled in the two villages. A simple religious learning system. The pattern is as elsewhere unstructured. Learning to read Qur'anic verses was given after Maghrib prayer. Prayer is more pressed on habituation. Similarly, morality, creed, fiqh, and others.

Religious studies in the home are generally delivered by parents who are not from the Lom. For those who are Muslims, implementing principles of Islamic teachings, in addition to the obligation, strengthens the existence of Muslims. However, Islam was more developed through the process of socio-cultural interaction. Islam in the quality dimensions of the implementation was still low. Islam was a predominantly Islamic religion. As a majority quantity, Muslims have not been able to be dominant, especially in Air Abik. Indigenous peoples shackled Muslims.

\subsubsection{Islamic preaching activities}

The study was intended to be the process of delivering the teachings of Islamic religion individually and collectively. This study could be understood as part of the da'wah and transformation of Islamic religious values through the process of education. The study material contained learning Qur'an reading, prayer guidance, and deepening of jurisprudence problems. The study was formatted in several forms, namely; First, religious studies for the public; Second, the study of mothers; and third, education for children.

General studies were given by all circles. In the hamlet of Pejem, studies were held at Masjid. Air Abik was held in a residential house and is limited. Mothers were more takmir mothers. Its activities were Yasinan, Tahlilan, and learning about Islamic materials while the children's studies were more learning to read the Qur'an, study, prayers, and fiqh.

\subsubsection{TPA/TPQ Activities}

By the year 1990, the lively TPA institution was carried out almost all over Indonesia. TPA was transformed into an Islamic education model outside of school. TPA was the pattern of the culture of Islamic values for children. TPA was also a learning alternative to reading Qur'an. Methods used were generally called the Iqra method. In Pejem, since the Iqra method was introduced throughout Indonesia, the TPA institution was held in the Mushalla. The children were learning in elementary school, also followed in TPA, both the children of Islam and the Lom. The material was conveyed, besides learning to read the Qur'an in the form of memorization of short verses (Juz ' Amma and selected verses), and the guidance of prayers. The material was delivered by a religious teacher (afternoon three times a week). This pattern was still preserved until now. In the evening, the material was also conveyed by religious figures (people who were active as a manager of Mushalla or mosque). 
Early learning about Islam has a significant role in transforming Islamic values. The transformation of Islamic values through the process of education, both at school and outside the school, is the foundation for the introduction of Islamic religious principles. This model could serve as a persuasive strategy of Islamic teachings, peace, and without compulsion. The transformation of Islamic teaching values raises First, an adaptation of the practice of Islamic teachings; Second, acculturation of Islamic social and cultural elements; Formal identity of belief.

\subsubsection{Education through information media}

Education containers are not only focused on formal Islamic learning. A media information can also be considered as a source of education. Sources of information in the form of televisions, mobile phones, and print media. Information media can motivate the strengthening of the latent function of Islamic education. Broadcasts and television shows will give effect to themselves. This is because almost all the Lom people have televisions. What they see on television shows can be a source of adaptation. Self-adjustment is not only in trend mode, but it does include behavioral ways.

Judging from the geographic people of the Lom, they settled on the geographical environment of technological outreach. This residential environment will allow adapting. The condition is by the disclosed environment that can be used as a critical concept in ecologicalcultural orientation. Adaptation is a process that connects the cultural system to the environment. According to the environment, the Lom experienced a paradigm change in the ecological and life-based.

\section{Conclusion}

Research findings showed that the Conversion of the Lom's belief occurs after performing of Islamic teaching or the term transformation of Islamic religious education. Conversion of beliefs from ancestral beliefs to Islamic believers was the leading choice. In addition to the religion of Islam approaching old belief, formal education of Islamic studies became a curriculum in elementary school. Even learning Islamic religion needs to be done because the Lom settled in the same geographic with the adhered to Islam and the majority community.

Nevertheless, their acceptance of Islamic education lessons in schools differed between the Lom, who settled in the hamlet of Air Abik with the hamlet of Pejem. This distinction was based on the attitude of ancestral trust protection. However, they did not prohibit his children from learning Islamic religious lessons in schools and communities. The Lom in Air Abik was relatively closed compared to the Lom in Pejem. They believed that the sacral area was called Bubung Tujuh in Air of Abik.

The attitude of acceptance of formal religious teachings such as Islam, Christianity, and others has an impact on the quantity of Conversion of belief to the attitude of Islamic religion, especially. Quantitatively, the Lom preferred Islam as a religion adopted both in Air Abik and Pejem. However, the people of Lom Air Abik, in addition to Islam as an option, partially chose Christianity as religion. It was based on the presence of a house of worship, Mushalla, the hamlet of Pejem, and the church in the hamlet of Air Abik.

The Lom has its uniqueness and characteristics. Field facts identify that the Conversion of the Lom's belief occurred after a long period of contact with Islam. Conversion of ancestral beliefs was strengthening through the transformation of Islamic religious education both in school and outside school. The transformation became a dominant factor, besides marriage. 
Conversion occurred after the process of adaptation, acculturation, and integration to Islam, both as a system of belief, culture, values of religious teachings. This proved that the Talcot Parsons theory could be used as a theory in reviewing the belief conversion of the Lom. Conversion of beliefs from ancestral beliefs to religiously-Muslims as a dominant choice other than Christianity and Khonghucu - suggested that Tylor's theory can be a grand theory. According to Tylor, the belief of the primitive society will experience the evolution of polytheism into monotheism. However, Lom cannot be portrayed as a primitive society since the Lom people have adopted modern technology and information. They have a phone, a television, including modern transport. They also lived with the religious community and always interacted with the outside world.

Nevertheless, the Lom has its uniqueness, Conversion of belief as ancestral belief turned into the majority of Islamic believers. However, the Lom could not release the ancestral culture, except for those who had moved from the two hamlets. The ancestral tradition was still a role model. This attitude is taken to avoid the "Kualat" or ancestor cursed.

\section{References}

[1] O. H. Smedal, Order and Difference: An Ethnographic Study of Orang Lom of Bangka, West Indonesia, no. 19. Department of Social Anthropology, University of Oslo, 1989.

[2] T. Horsfield, Report on the Island of Banka. 1848.

[3] S. Sujitno, "Legenda dalam Sejarah Bangka," Jakarta Cempaka Publ., 2011.

[4] S. Soekanto, "Hukum Adat Indonesia. Edisi 1 Cetakan 4," Jakarta. PT. Raja Graf. Perkasa, 2001.

[5] L. J. Zelle, "Les Maporais,” Bull. Mem. Soc. Anthropol. Paris, vol. 2, no. 1, pp. 214 221, 1891.

[6] G. Ritzer and B. Smart, "Handbook teori sosial," 2011.

[7] B. Raho, Teori Sosiologi Modern. 2007.

[8] D. L. Pals and S. J. G. Frazer, "Eight theories of religion," 2006.

[9] Koentjaraningrat, Pengantar Ilmu Antropologi. Jakarta: Rineka Cipta, 2009.

[10] Koentjaraningrat, Sejarah Teori Antropologi II. Jakarta: UI Press, 2010.

[11] A. Briggs, Sejarah sosial media. Yayasan Obor Indonesia, 2006.

[12] A. Montago, "Harsojo, Pengantar Antropologi." Bandung: Bina Cipta, 1982.

[13] A. R. Manners and D. Kaplan, "Teori Budaya," Yogyakarta: Pustaka Pelajar, 2002. 